\title{
The Multiliteracy Pedagogy for Teaching Speaking To Enhance The Students' Higher Order Thinking Skills (HOTS)
}

\author{
M. Nawawi ${ }^{1}$, A Christanti $^{2}$, A.Izzudin ${ }^{3}$, M. Laili ${ }^{4}$ \\ English Language Education ${ }^{124}$, 3Elementary School Teacher Education Department, Nahdlatul \\ Ulama University of Sidoarjo ${ }^{3}$ \\ \{alexnawawi.pbi@unusida.ac.id\}
}

\begin{abstract}
This study aims to describe the implementation of Multiliteracies Pedagogybased instructional on teaching Public Speaking to enhance The Students' Higher Order Thinking Skills (HOTS). It is descriptive qualitative research with observation and questionnaire data collection techniques. The research instruments are field notes and the questions of the questionnaire sheet. There are ten questions about the instructional process in it. The subjects of the research are the lecturer of Public Speaking and the twenty students of the English Language Education of Nahdlatul Ulama University of Sidoarjo (UNUSIDA) in the third semester. The lecturer has developed the teaching-learning activities into four steps: Situated Practice, Overt Instruction, Critical Framing, and Transformed Practice with their knowledge process in every syntax. The researcher observes the implementation of the lesson in the class, and how the students respond to it. Then, at the end of the activities, the students write his opinion about the learning process in the questionnaire. The observation shows that the lecturer has applied the four syntaxes of the multiliteracies pedagogy completely in the classroom. The lecturer, automatically, has enhanced the students' thinking skills by following the syntax of the multiliteracy pedagogy model. The students' opinion about the teaching-learning process is good with an average of $96,5 \%$ of their responses to the questionnaire stated positively. It is suggestive to the next researchers may do any experimental research about the effectiveness of the model for enhancing the students' higher order thinking skills in Elementary or High Schools.
\end{abstract}

Keywords: Multiliteracy Pedagogy, HOTS, Multiliteracies Pedagogy-Based Instructional

\section{Introduction}

Speaking, as one of the productive skills, is the ability to use language orally with sound to give information, express ideas, and deliver meaning to interact with another community member. Speaking, in English Language Education Department, is usually taught in the first and second years in different course objectives. The main objective of teaching speaking in the department is to train the students to speak fluently, fluency, and accuracy. The students need particular skills, such as the capability of formulating statements using correct vocabulary and grammar, delivering messages through expression, intonation, and gesture appropriately, and so on to get success in communication. 
Strategies in teaching play an important role in helping the students to speak well. Teachers can determine their success in achieving the goals of teaching with appropriate teaching strategies. Williams, M, and Burden stated that teaching strategies are an important factor in determining failure or success in language learning [1]. Strategies can help the lecturers to decide language instructions and how they are conducted. Reiser, R. A., \& Dick suggested that teachers should use various teaching methods to achieve goals and objectives for teaching [2] These mean that teachers have to make students speak English through effective teaching strategies.

Strategies in teaching language are very important to resolve speaking problems for students. Speaking strategies can help students better speak fluently and accurately. Brown mentioned that every teacher may use various techniques to enhance their skills. Following the steps of strategies, teachers can see how students' comprehension of language learning can be effective and ineffective and can build a milieu in a classroom to realize effective strategies [3]. It is critical, however, that the implemented strategy is specific to the students' needs and interests.

The research done by Kharisma showed that the English Language Education Students of Nahdlatul Ulama University Sidoarjo (UNUSIDA), especially in the fourth semester, have anxiety problems in speaking class. The factors of student's speaking anxiety in speaking class are their over self-prediction toward fear, irrational faith to say something in English, the sensitivity of anxiety, wrong attribution of body signal because they cannot express their ideas in English well, and low self-efficacy. The researcher found the causes of studentls speaking anxiety are fear, worry, heart breathed fast, feel nervous, tremble, and panic, cannot control their body language, shy, and less confident to speak in English especially in speaking class[4]. The lecturer, then, tries to implement an interesting strategy to solve the problem.

The lecturer of speaking class at Nahdlatul Ulama University Sidoarjo has implemented the Multiliteracy Pedagogy model as a strategy to enhance students' speaking as well as thinking skills. Yen and Halili stated that over the decades, the goal was to grow and enhance the HOT for students [5]. Most teachers agree that it is important that students are taught HOTS primarily to help generate their ideas. The commitment to HOTS is important to global economic growth, the production of ICT, a knowledge-based economy, and a rapidly changing global climate. In fact, in any educational environment, HOT is a very important skill for every person.

The teachers need to design the instructional with an appropriate model or strategy to help the students to think. There must be a process of generating ideas structurally. Heong, et.al argued that the idea generation process takes place through restructuring and new relations between knowledge and experience [6]. The information provides the basis for ideas and the production of ideas will not start without information. To produce new ideas, knowledge must also be gathered, restructured, and analysed in the right brain. This shows clearly that ideas are generated by a thought method. But dreaming isn't a simple job because it takes an efficient process and expertise to produce ideas in particular. But an idea can be produced more easily with experience, knowledge, and thought skills. Rajendran, therefore, stated that models, methods, techniques, and exercises are models of lessons that illustrate how to teach thinking skills along with subjects using an integrated approach [7]

Besides, the teachers must prepare the learning resources well to support the students' way of thinking. Nachiappan, et.al mentioned that the resource materials must be designed to ensure the successful implementation of HOTS to recognize, represent, and overcome issues, determine, innovate, and build information, skills, and value that students gain [8]. The compilation of resources can allow students to engage with the content through difficult learning 
that students use HOTS. A variety of tools is required to account for ongoing academic activity within the classroom (e.g. computers, reference books, journals, etc).

The multiliteracy pedagogy is the answer to the teachers'need of enhancing HOTS in the classroom. There are, still, few teachers familiar with the model in Indonesia, however, it is popular abroad. The Multiliteracy Pedagogy was introduced by the New London Group in the 1990s. Experts and colleagues, at that time, has concerned about language and education. They discussed what was going on in language and literacy teaching in schools as well as what was in the field of communication.

The technology development presence in schools and children's lives presents a challenge for traditional instructional tools. Burke \& Hardware argued that contrary to the common structured and monomodal methods used to assess knowledge in most of our education systems, multilateral pedagogy encourages students to convey knowledge in various modes that naturally complement all five senses [9]. Besides, Cope etc implied the necessity of being multiliterate in today's working life. The teachers, therefore, should take a care pathway that offers students the opportunity to develop future job skills by studying the new working language [10]. Students need to develop the capacity to talk, to negotiate, and to be able to objectively interact with working conditions as well as their thinking skills.

The lecturer of the Speaking subject, therefore, changes her way of teaching into the new one, following the syntax of the Multiliteracies pedagogy; Situated Practice, Overt Instruction, Critical Framing, and Transformed Practice. Kalantziz and Cope have redesigned those concepts and transposed them into pedagogical actions or processes of knowledge; they are experiencing, conceptualizing, analyzing, and applying [11]. It is more applicable and easier for the lecturer to develop her instructional based on the model. The lecturer has changed her teaching preparation into the Multiliteracy pedagogy model and tried to implement it as well.

The researcher, therefore, needs to describe how the lecturer redesigns her instructional in Public Speaking Subject; from the lesson plan, the teaching-learning process in the classroom, the process of enhancing students' HOTS, and the students' response to the class as well. The lecturer intends to enhance the students' speaking ability as well as higher order thinking skills by pressing their problems with anxiety in learning.

\section{Research Methods}

It is a descriptive qualitative research that reveals the lecturer's implementation of the Multiliteracy pedagogy based instructional. The data collection techniques are observation and questionnaire. The researcher has done an observation to the lecturer by field notes and given a questionnaire to the students at the end of the class by google form. The researcher has observed the lecturer's process of developing a lesson plan and media, then implementation in the class. The research subjects are the lecturer of Public Speaking and the twenty students of the third semester or the 2019 students of English Language Education Department UNUSIDA. The researcher has observed two meetings of the Public Speaking class. Every meeting has its lesson plan. The focus of the observation is on the teaching-learning process that enhances students' thinking skills as well as their speaking ability.

The researcher, then, distribute the link of the questionnaire to the students at the end of the second meeting. There are 10 (ten) questions in the questionnaire about the teaching-learning process with the Multiliteracy pedagogy model. The research reveals the lecturer's performance, media used, and the activities in the class. 


\section{Results and Discussion}

The lecturer started to improve the instructional by revising the lesson plan. The lecturer divided the teaching-learning process into three phases: opening, learning activities, and closing. There are four steps in the learning activities; Situated Practice, Overt Instruction, Critical Framing, and Transformed Practice based on the Multiliteracy pedagogy model. The previous lesson plan did not have the steps. The learning objective is the students can make and perform a monologue that indicates speaking to inform, speaking to persuade, or speaking to entertain. The operational verb "make and perform" belongs to the creating level of Bloom Cognitive taxonomy (C6). The lecturer has mentioned the Higher Order Thinking Skills (HOTS) category of learning objective to guide the instructional process.

The indicators for achieving the learning objective have been ordered from lower thinking skills to the higher one $(\mathrm{C} 1-\mathrm{C} 6)$. The first indicator is identifying the content of a video about kinds of speaking (C1). The second one is explaining the content of a video about kinds of speaking (C2). Next is discovering the component of speaking to inform, to persuade, and to entertain (C3). The next level is analyzing the component of a text about speaking to inform, to persuade, and to entertain, (C4), then criticizing the report (C5), and the last is performing speaking to inform, persuade, or entertain correctly and fluently (C6). The lecturer has combined the level of Bloom taxonomy with the multiliteracy pedagogy syntax in the main activities of the teaching-learning process.

The first activity is Situated Practice. Cope \& Kalantzis mentioned that there is two knowledge process involved in this phase; Experiencing the known and Experiencing the new [12]. Experience the known means to experience what is understood that is to learn about our own experiences, interests, opinions, common terms, and ways to represent the world in your way. Students in this respect bring their information, perspectives, ambitions, and constantly varied interests learning condition life-texts. The lecturer, in this process, asked the students to make a list of activities that they have ever done relating to speaking purposes. Here, the lecturer explored the students' prior knowledge about Public Speaking. They can write about their experiences as much as possible. Then, she asked them to tell it to the class.

Then, she played three short videos that show activities of speaking to inform, persuade, and entertain. The Students watched and observed the video based on the lecturer's questions; what does the man/woman do? where is the setting? what is her/his objective?. The lecturer explores the students' prior knowledge by questioning. The lecturer, then, discussed the students' answers. She gave the same opportunity for active and silent students to involve in the discussion. They were feeling free and relax to talk to her. The activities were categorized "Experiencing the new" since the students entailed observing or reading the unfamiliar, immersion in new situations and texts, reading new texts, or collecting new data. It is the process of thinking started. New knowledge, experiences, and texts are only accessible to students. In the field of intelligibility and protection, near enough to your life-worlds in the first place must be at least half meaningful but potentially transformational insofar as weaving between the known and the known. The new fields of action and sense take the learner new.

The next phase of pedagogy multiliteracy is Overt Instructions which are all the things carried out in the classroom to improve the knowledge and skills of students, including lectures, openers, packaging, modifications, and evaluation aspects. This phase does not require direct 
information transmission, exercises, or rote education. Instead, it is a much more fluid technique that allows teachers to apply their talents and abilities to build on students' present level of comprehension within a learner group. Two cognitive processes are coming up at this level; Conceptualizing by naming and Conceptualizing with theory [12]. The lecturer guided the students, in Conceptualizing by naming, to categorize the activities in the video in a group. The students have made various categories such as news speaking, trading speaking, speaking to amuse, etc. They knew that the purpose of speaking is different from one to another, however, they did not conclude yet.

Next, the lecturer gave a text to the students to read. It is a theory of public speaking. She asked them to make a categorization of speaking in the video based on the text. To conceptualize theory is to generalize and place in interpretative frameworks and key terms together. The lecturer divided them into groups of five and asked them to analyze the text to conclude the concept of speaking to inform, speaking to persuade, and speaking to entertain. They related the theory to the examples from videos and their own experiences. They wrote a table of criteria about the concept of speaking. The lecturer asked each group to presents the result of their discussion. Each group presented the result of their discussion. The lecturer and students, then, conclude the result of the students' discussion. The tasks under this category required a deeper understanding of the textual structures and connections than in conceptualizing by naming.

The next syntax of the instruction belongs to the Critical Framing phase. The third component of multiliteracies pedagogy is one of the most powerful aspects of learning. Critical framing aims at continuously questioning their learning and literate practice concerning the relationships between historical, political, ideological, and value-centric knowledge and social practice in particular structures. Critical framing exercises involve students in activities in which the layers are broken down into a text and the pieces are evaluated in terms of structure, multimodality, expression, and/or function. The overarching objective of critical framing is to enhance students ' capacity to test their perceptions, as well as those imbued in the text itself.

There are two kinds of cognitive processes involved in this Critical Framing; they are analyzing functionally and analyzing critically [12]. The activities that were viewed as targeting analyzing functionally usually required the students to understand the information that they were working on more profoundly. Jarho stated that the students had to draw conclusions and rely upon their interpretation of the facts at hand [[13]]. These were usually not the first exercises that were implemented in any unit, but rather the middle and end of the training list. The functional analysis involves reasoning methods, the drawing of inferential and deductive conclusions, functional linkages between cause and effect, and analyzes of logical and textual associations.

The lecturer, in the analyzing functionally process, asked the students to search for a video or dialogue instrument that performs a speaking in a partner. It is on a free topic. After choosing one, they have to analyze what type of speaking it is and explain to the class their reason why they think so. The students must analyze every single expression in the dialogue/monolog they choose to conclude that it is categorized as speaking to inform, to entertain, or to persuade. Students investigate causes and consequences, establish reasoning chains, and clarify textual patterns. The activity took a long time that the students can finish their work at home. It is for the second meeting.

The next meeting started with students' presentations about their analysis of the homework. The lecturer asked the others to listen attentively and gave comments to their friends. It was the analyzing-critically process. Analyzing critically, more critically than functionally, involves the evaluation of one's and other people's perspectives, interests, and motives. In these knowledge processes, learners interrogate the interests behind a meaning or an action, and their processes 
of thinking. The activities which focused on the analysis invited the students to take account, for example, of the intentions behind the creation of texts. Students were also requested to be aware of the tools they used to search for online information [13].

The last phase of the multiliteracy pedagogy model is Transformed Practice. Multiliteracy theory seeks to ensure that our students gain the skills and conduct through the components of local experience, transparency, and critical framing and bring them into effect in real-world situations outside school. Mac Kay argued that transformed practice helps students to interact with themselves learning and integrating their cultural backgrounds, contributing to a certain degree of creative change. This method helps students to prevent their passivity of information which leads you to be information producers in ways that are important to you and the surrounding communities [14].

The lecturer, in this phase, divided the students into groups consists of three. Since the students are twenty that there are two groups consists of four. The lecturer asked them to perform speaking to inform, to persuade, and to entertain in a group based on their chosen situations. They performed it in front of the class like a role play. They were free to express their interest creatively. To apply creatively means to interfere in the world is genuinely innovative and imaginative and it makes the learner's contribution experience, desires, and expectations. It's a method to create the real world of new and innovative ways of action. Students do something that communicates the world in new ways or moves their previous experience into a new environment. The lecturer ended the instructional by concluding the topic together with the students. They have learned well about it and got meaningful knowledge, attitude, and speaking skills from the learning process.

The multiliteracy pedagogy model has helped the lecturer to arrange the teaching-learning process in the class. It is easier for her to conduct the activities based on the syntax. Even these pedagogical guidelines or processes of understanding are no particular pedagogy or a series to be followed. They are more a map of the range of educational movements that teachers may take to broaden their pedagogy. Didactic teaching underlines the open instruction of conceptual and disciplinary frameworks to the detriment of other pedagogical directions. A multidisciplinary pedagogy offers alternative learning points. It facilitates alternate ways of engagements, such as the varied learning experiences, different philosophical bends of learners, the various theoretical views of students on the essence of the cause, impact, and human interest, as well as the diverse settings through which they can bring their expertise into practice or practice. It permits different sense modalities. Make alternate expressive ability and promote synaesthesia as a learning technique for various learners.

The researcher, then, intended to know the students' opinions about the instructional by distributing a questionnaire. There are ten questions in the questionnaire. The questions are about; (1) students' opinion about the speaking class, (2) how the lecturer communicates in the class, (3) the lecturer guides the students to think or not, (4) the lecturer allows exploring information from various sources, (5) how the students follow the syntax of learning, (6) how the teaching media used by the lecturer, (7) the lecturer enhances students critical thinking or not, (8) the lecturer allows the students to express their creativity, (9) the students get new knowledge or not, and (10) the time is effective for learning. The result of the questionnaire shows that the students are happy and enjoy the class. 95\% of them stated that the class is interesting and enjoyable, they admitted that the lecturer communicated well in the instructional, they can follow the learning syntax easily, and they agreed that the time is effective for learning. All students (100\%) agreed that the lecturer guided them to think in the learning process, she supports them to search information from various sources, the media used in teaching is interesting, the lecturer allowed them to express their creativity, and they have got new 
knowledge and experiences from the class. There are $85 \%$ of students admitted that the lecturer has trained them to think critically, however, $15 \%$ of them (3 students) said no comment. Perhaps they do not understand what the question means. The result of the questionnaire can be described in the table follows.

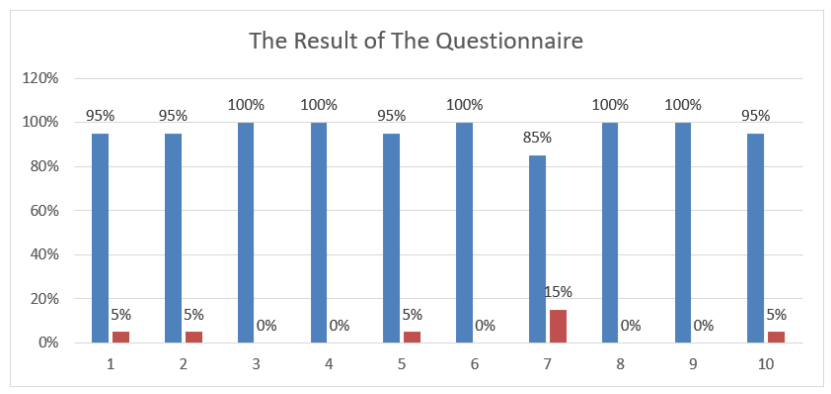

The lecturer has created an enjoyable situation of learning for students. They have chances to speak step by step. They just spoke to answer the lecturer's questions one by one in Situated Practice. Then, they tried to explain some information in the Overt Instruction. Next, they tried to give an opinion and argued with their friends in Critical Framing. Finally, they have to make and perform a monologue. The process of speaking is orderly well. The students can speak freely. The lecturer can minimize the students' anxiety by using interesting teaching media and other sources of learning, such as the internet and video. The concept of multimedia and multimodal in the multiliteracy pedagogy is in line with the need of students in learning.

Besides, by following the syntax of the multiliteracy model, the teacher has enhanced the students' thinking skills. In the Situated Practice, the knowledge process of experiencing the known and the new, she asked the students to identify a video. The students are still involved in the level of knowing of Bloom taxonomy or C1. Then, in Overt Instruction, the knowledge process of Conceptualizing by naming and Conceptualizing with theory, the students have activities in the level of understanding (C2) and applying (C3) of Bloom taxonomy since they have to understand the content of the video to make categorization.

In the next activities, they have the analyzing functionally knowledge process in the Critical Framing phase. The students got an experience to think higher since they have to analyze the components of the video or dialog. It belongs to the analyzing level of cognitive taxonomy (C4). Then, they evaluated others' work in the analyzing critically-knowledge process and it is the activity of the evaluating level of Bloom taxonomy (C5). The last activity, performing speaking in the Transformed Practice syntax, is the level of creating (C6) of the taxonomy. The lecturer has tried to enhance the students' thinking skills by following the pedagogy multiliteracy model in the teaching-learning process.

The model has been arranged to give experiences to the students thinking from lower to a higher level. The multiliteracy pedagogy, therefore, has been applied in many countries. They have been drawn to multi-lingual, multiethnic, multi-religious pedagogy following dramatic advances in information and communication technology use there. These innovations have been advocated as important resources to lead people in evolving times in their learning, economic, and social lives. The New London Group's multiliteracy system gave a valuable point of view to think about the provision of education that will give the students the knowledge and skills they need to be involved and educated people and staff in a changing world - a world of diversity that rapidly shifts our connectivity and access to information. 
Teachers in Indonesia are not familiar yet with the pedagogy multiliteracy model. Many of them, however, have realized the importance of multiliteracy today. They know that multiliteracy ability is a skill for someone to help in understanding knowledge. Multiliteracy ability is very useful, especially in the world of education, students will more easily understand the materials given by the teacher. And the teacher also has to adapt to this new knowledge. The emergence of multiliteracy skills is due to the very rapid development of information and communication technology.

\section{Conclusion}

Based on the description above, the researcher can conclude that the lecturer has successfully changed her instructional based on the Multiliteracy pedagogy model and it satisfies the students. The lecturer follows the syntax of the model fully in the main activities, starting with Situated Practice; with the knowledge process of experience the known and experience the new. The second syntax is Overt Instruction with the knowledge process of Conceptualizing by naming and Conceptualizing with theory. Then, the Critical Framing phase with analysing functionally and analysing critically the knowledge process. And the last, Transformed Practice with applying appropriately and applying creatively the knowledge process.

Besides, the lecturer has enhanced the students' thinking skills by following the syntax of the multiliteracy pedagogy model. All indicators, from $\mathrm{C} 1$ - C6 of Bloom taxonomy can be applied easily because of the multiliteracy model. It showed that the model is appropriate to enhance the thinking skills of students. The students' opinion about the teaching-learning process is good with an average of $96,5 \%$ of their responses to the questionnaire stated positively.

It is for teachers in Indonesia that need to broaden their mindset of teaching, not only use the same teaching model for a long time repeatedly but also try a new syntax of multiliteracy model that is suitable for education today. The teachers need to practice Multiliteracy pedagogy based on instructional. Multiliteracy with multimodal and multimedia is needed to enhance the students' thinking skills. For the next researchers may do any experimental research about the effectiveness of the model for enhancing the students' higher order thinking skills in Elementary or High Schools.

\section{References}

[1] R. L. Williams, Marion, and Burden, Psychology for Language Teachers: A Social Constructivist Approach, vol. 33, no. 1. 2003.

[2] W. Reiser, R. A., \& Dick, "Instructional Planning: A Guide for Teachers 2nd Edition," Boston: Al., Boston: Allyn and Bacon., Ed. Boston: Boston: Allyn and Bacon., 1996, p. Boston: Allyn and Bacon.

[3] H. D. Brown, Principles of Language Learning and Teaching, vol. 57, no. 3. 2000.

[4] S. M. Kharisma, "Speaking Anxiety in Public Speaking Class Faced by The Fourth Semester Students of English Education Department of Nahdlatul Ulama University of Sidoarjo," Nahdlatul Ulama University of Sidoarjo, 2020.

[5] [5] T. S. Yen and S. H. Halili, "EFFECTIVE TEACHING OF HIGHER-ORDER THINKING ( HOT ) IN EDUCATION,” Online J. Distance Educ. e-Learning, vol. 3, no. 2, pp. 41-47, 2015. 
[6] [6] Y. M. Heong, J. M. Yunos, W. Othman, R. Hassan, T. T. Kiong, and M. M. Mohamad, "The Needs Analysis of Learning Higher Order Thinking Skills for Generating Ideas," Procedia - Soc. Behav. Sci., vol. 59, pp. 197-203, 2012.

[7] R. Nagappan, "Language Teaching and the Enhancement of Higher-Order Thinking Skills," in In Language curriculum and instruction in multicultural societies - Anthology series 42., no. April 2000, 2001.

[8] S. Nachiappan, A. A. Damahuri, C. Ganaprakasam, and S. Suffian, "APPLICATION OF HIGHER ORDER THINKING SKILLS ( HOTS ) IN TEACHING AND LEARNING THROUGH COMMUNICATION COMPONENT AND SPIRITUAL, ATT," Int. J. Early Child. Educ. Care, vol. 7, no. December, pp. 24-32, 2018.

[9] A. Burke and S. Hardware, "Honouring ESL students' lived experiences in school learning with multiliteracies pedagogy," Lang. Cult. Curric., vol. 28, no. 2, pp. 143-157, 2015.

[10] J. et al Cazden, Courtney; Cope, Bill; Fairclough, Norman; Gee, A pedagogy of multiliteracies: Designing social futures, vol. 66, no. 1. Harvard Educational Review, 1996.

[11] B. Cope and M. Kalantzis, "Multiliteracies": New Literacies, New Learning, vol. 4, no. 3. 2009.

[12] Bill C. and M. Kalantziz, Multiliteracies: Literacy Learning and The Design of Social Futures. 2005.

[13] E. Jarho, "The Knowledge Processes Framework and Multiliteracies in Upper Secondary School English Textbooks ENA 3 Cultural Phenomena," University of Tampere, 2017.

[14] T. MacKay, "Multiliteracies Theory Into Practice: An Inquiry Into Junior -Level Literacy Classroom," University of Toronto, 2014. 